\section{BRAZIULIAN JOURNAL}

OF MEDICAL AND BIOLOGICAL RESFARCH

www.bjournal.com.br
ISSN 0100-879X

Volume 43 (9) 812-913 September 2010

BIOMEDICAL SCIENCES

AND

CLINICAL INVESTIGATION

Braz J Med Biol Res, September 2010, Volume 43(9) 821-827

doi: 10.1590/S0100-879X2010007500084

Caspase-8 and p38MAPK in DATS-induced apoptosis of human CNE2 cells

C. Ji, F. Ren and M. Xu

The Brazilian Journal of Medical and Biological Research is partially financed by
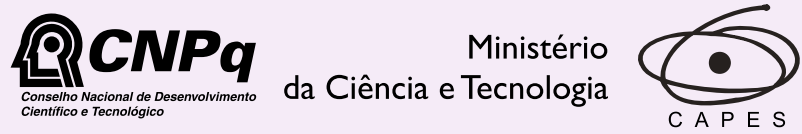

Ministério da Educação

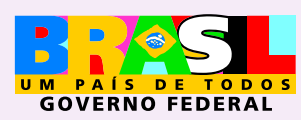

DFAPESP

Institutional Sponsors
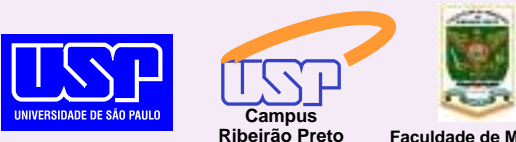

Ф SHIMADZU

GE Healthcare
Hotsite of proteomics metabolomics developped by: 


\title{
Caspase-8 and p38MAPK in DATS-induced apoptosis of human CNE2 cells
}

\author{
C. Ji ${ }^{1}, \mathrm{~F} \cdot \mathrm{Ren}^{1}$ and M. $\mathrm{Xu}^{2}$ \\ ${ }^{1}$ College of Chemistry and Chemical Engineering, \\ ${ }^{2}$ Research Institute for Molecular Pharmacology and Therapeutics, \\ Central South University, Changsha, Hunan, China
}

\begin{abstract}
Nasopharyngeal carcinoma is a common malignancy in Southern China of uncertain etiologic origin. Diallyl trisulfide (DATS), one of the major components of garlic (Allium sativum), is highly bactericidal and fungicidal. In this study, we investigated the function of p38 mitogen-activated protein kinase (MAPK) and caspase-8 in DATS-induced apoptosis of human CNE2 cells using MTT [3-(4,5-dimethylthiazol-2-yl)-2,5-diphenyltetrazolium bromide], flow cytometry assay, and Western blotting. After CNE2 cells were treated with DATS $(50,100$, or $150 \mu \mathrm{M})$ for $24 \mathrm{~h}$, cell viability rates were $75.9,63.4$ and $39.6 \%$, and apoptosis rates were $24.5,36.9$, and $62.4 \%$, respectively. The data showed that DATS induced CNE2 cell death in a dose-dependent manner. After human CNE2 cells were treated with $100 \mu \mathrm{M}$ DATS and inhibitors (10 $\mu \mathrm{M}$ SB203580 and Z-LETD-FMK for p38MAPK and caspase-8, respectively), changes in cell viability and apoptosis and in p38MAPK and caspase-8 activity were detected. Cell viability rates were 66.5 and $68.1 \%$ and decreased 9.9 and $11.5 \%$ compared with inhibitor treatment alone. Apoptosis rates were 31.53 and $29.98 \%$ and increased 9.1 and $10 \%$ compared with inhibitor treatment alone. The results indicated that DATS activates p38MAPK and caspase-8, but both inhibitors have an effect on P38MAPK and caspase-8 activity. In conclusion, our data indicate that p38MAPK and caspase- 8 are involved in the process of DATS-induced apoptosis in human CNE2 cells and interact with each other.
\end{abstract}

Key words: DATS; p38 MAPK; Caspase-8; Inhibitor; Apoptosis

\section{Introduction}

Mitogen-activated protein kinase (MAPK), an important intracellular signal transduction system, has a marked effect on the regulation of gene expression and cytoplasmic functional activities (1-3). The p38 signaling pathway is an important branch of the MAPK pathway, playing a significant role in a variety of physiological and pathological processes, such as inflammation, cell stress, apoptosis, cell cycle and growth, and so on $(4,5)$. Caspase is an inactive enzyme zymogen under normal circumstances, but once activated it will trigger the caspase cascade, eventually leading to apoptosis. In the central control and effective stage of apoptosis, activated caspase-8 can lead directly to the appearance of apoptotic structural characteristics in cells, and play a key role in the process of apoptosis $(6,7)$.

Nasopharyngeal carcinoma (NPC) is a malignant tumor of high incidence in the Southeastern region of Asia. In clinical practice, NPC is treated by radiation, but the therapeutic effect is not satisfactory (8-10). In recent years, many investigations have focused on extracting active ingredients from natural plants to prevent and treat cancer and to investigate their anti-cancer mechanism $(11,12)$. Garlic (Allium sativum) is a common plant used mainly as a food and is considered to have medicinal properties in many cultures (13). Allicin is a general name for the main bioactive component of garlic, which is a compound of a variety of allyl sulfides (14-17). Diallyl trisulfide (DATS), the major component of allicin, has anti-inflammatory and antibacterial functions. However, DATS is an unstable compound that can be easily converted to diallyl disulfide during the extraction process due to external factors. Studies have shown that DATS can inhibit the growth of human tumor cells such as prostate cancer cells and gastric cancer cells (18-22). In the present study, we used SB203580, a p38MAPK inhibitor, and Z-LETD-FMK, a caspase-8 inhibitor, to determine the relation of p38MAPK and caspase-8 in the apoptosis process induced by DATS. We observed

Correspondence: F. Ren, College of Chemistry and Chemical Engineering, Central South University, Changsha, Hunan 410083, China. Fax: +86-731-8883-6993. E-mail: Renfl2009@yahoo.com.cn

Received April 15, 2010. Accepted August 5, 2010. Available online August 27, 2010. Published September $13,2010$. 
that $\mathrm{p} 38 \mathrm{MAPK}$ and caspase- 8 are involved in the process of DATS-induced apoptosis in human CNE2 cells and interact with each other.

\section{Material and Methods}

\section{Material}

DATS (99\% purity) was purchased from Chia-tai Tianqing Pharmaceutical Co., Ltd. (China). RPMI1640, BSA and SB203580 were purchased from Sigma (USA). Z-LETDFMK was purchased from Biovision (USA), goat horseradish peroxidase (HRP)-conjugated anti-rabbit secondary antibody was purchased from Santa Cruz Biotechnology (USA). Antibodies to p38, phospho-p38 (p-p38), and caspase-8 were purchased from Cell Signaling (USA).

\section{Cell culture}

CNE2, a human NPC cell line, was provided by the Xiangya School of Medicine and cultured in RPMI1640 containing $10 \%$ heat-inactivated fetal bovine serum (FBS), benzylpenicillin $(100 \mathrm{kU} / \mathrm{L})$ and streptomycin $(100 \mathrm{mg} / \mathrm{L})$ at $37^{\circ} \mathrm{C}$ in an incubator containing humidified air with $5 \%$ $\mathrm{CO}_{2}$.

\section{Cell viability assay}

Cells were seeded onto 96 -well plates at $1 \times 10^{4}$ cells per well $24 \mathrm{~h}$ before treatment. The cultures were then rinsed in phenol-free RPMI1640 medium and incubated with the respective test substances in phenol-free and serum-free RPMI 1640 for $24 \mathrm{~h}$. In the inhibition test, cells were treated with DATS after being treated with inhibitors for $30 \mathrm{~min}$. At the end of this time, $20 \mu \mathrm{L}(5 \mathrm{mg} / \mathrm{mL})$ MTT [3-(4,5-dimethylthiazol-2-yl)-2,5-diphenyltetrazolium bromide] was added to each well, and after incubation at $37^{\circ} \mathrm{C}$ for $4 \mathrm{~h}$ the MTT solution was removed and $200 \mu \mathrm{L}$ dimethylsulfoxide (DMSO) was added to dissolve the crystals. The absorbance of each well at $570 \mathrm{~nm}$ was measured.

\section{Flow cytometry analysis}

Cells $\left(12 \times 10^{6}\right)$ were seeded into $100-\mathrm{mL}$ cell culture bottles $24 \mathrm{~h}$ before treatment and then treated as described above and incubated for $24 \mathrm{~h}$. Cells were then collected and

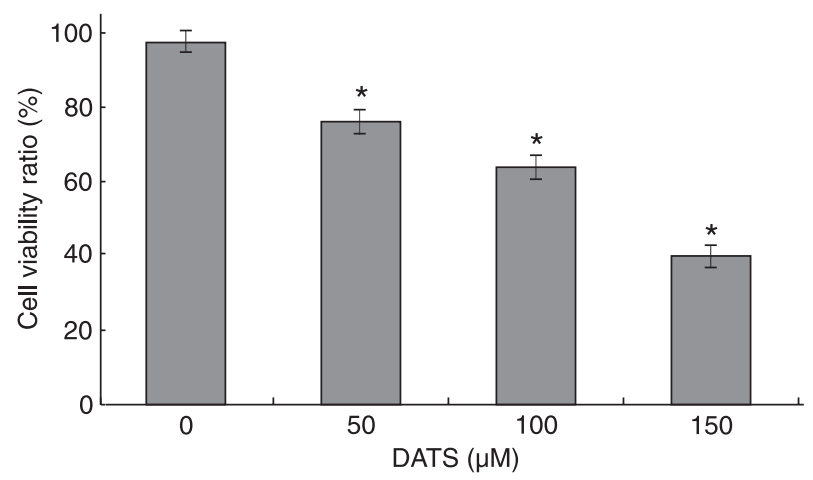

single cell suspensions were prepared and centrifuged at $800 \mathrm{~g}$ for $5 \mathrm{~min}$. The supernatant was discarded and cells were washed three times with cool PBS and fixed for 24 $\mathrm{h}$ with cool alcohol at $4^{\circ} \mathrm{C}$. One-milliliter cell suspension $\left(10^{6} / \mathrm{mL}\right)$ was washed three times with cool PBS, treated with RNase for $30 \mathrm{~min}$ at $37^{\circ} \mathrm{C}$, stained with propidium iodide $(\mathrm{PI})$ for $30 \mathrm{~min}$ at $37^{\circ} \mathrm{C}$ in the dark, and used for flow cytometry analysis.

\section{Western blotting}

Cells in the logarithmic growth phase were treated as described above and incubated for $24 \mathrm{~h}$. After fragmentation on ice for $20 \mathrm{~min}$, the lysates were centrifuged at 15,000 $\mathrm{g}$ for $10 \mathrm{~min}$ at $4^{\circ} \mathrm{C}$, the protein was collected, quantitated by the bicinchoninic acid (BCA) method, electrophoresed and isolated by $10 \%$ SDS-PAGE using the electrotransfer method, blocked, and hybridized on cellulose nitrate film. The protein expression of the cells was detected using the ECL Western blotting method. The densities of protein bands were calculated using the Quantyone software.

\section{Statistical analysis}

Data are reported as means \pm SD of three independent experiments and were evaluated by one-way analysis of variance (ANOVA). Differences were considered to be significant at $P<0.05$.

\section{Results}

\section{Changes in cell activity}

We tested the effect of DATS on human CNE2 cells. The cells were treated with various concentrations of DATS for $24 \mathrm{~h}$ and cell viability was determined by the MTT assay. As shown in Figure 1, $50 \mu$ M DATS induced a $75.9 \%$ decrease in cell viability. When the cells were incubated with 100 and 150 $\mu$ M DATS, cell viability decreased by about 63.4 and $39.6 \%$, respectively, at $24 \mathrm{~h}$. DATS had a dose-dependent effect.

The MTT conversion assay was used to test the effects of inhibitors on the viability of CNE2 cells. After treatment with $10 \mu \mathrm{M}$ SB203580 or Z-LETD-FMK for $30 \mathrm{~min}, 100 \mu \mathrm{M}$ DATS induced a 66.5 or $68.1 \%$ decrease in cell viability at $24 \mathrm{~h}$. When the cells were incubated with $10 \mu \mathrm{M}$ SB203580
Figure 1. Effect of diallyl trisulfide (DATS) on cell viability. CNE2 cells were treated with $0,50,100,150 \mu \mathrm{M}$ DATS for $24 \mathrm{~h}$. Cell viability was determined by MTT assay. Data are reported as means $\pm \mathrm{SD}$ of three independent experiments. ${ }^{*} \mathrm{P}<0.05$ compared to control (one-way ANOVA). 
or Z-LETD-FMK, cell viability decreased by about 76.4 or $79.6 \%$ at $24 \mathrm{~h}$ (Figure 2).

\section{Flow-cytometry analysis of apoptosis}

To further examine the effects of DATS on apoptosis, flow
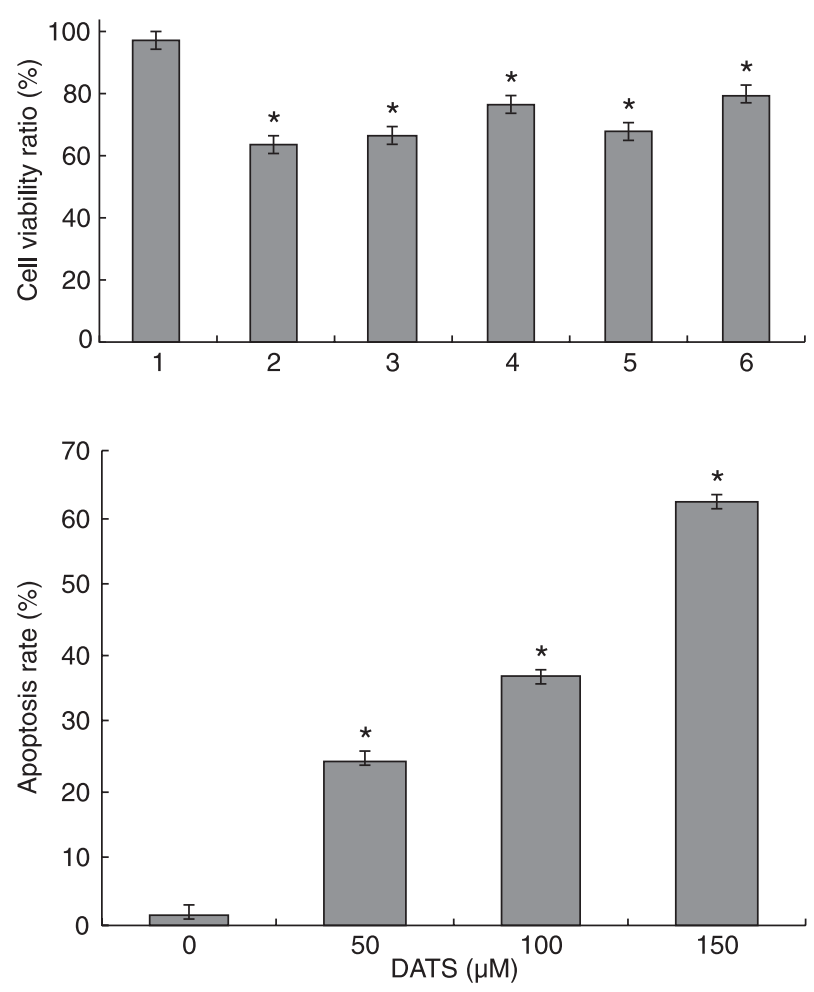

cytometry was used to quantify the apoptotic state. We found that $24.5,36.9$, and $62.4 \%$ of CNE2 cells became apoptotic when they were exposed to 50, 100, $150 \mu \mathrm{M}$ DATS for 24 h (Figures 3 and 4). These results supported the view that DATS induces apoptosis of CNE2 cells in a concentration-

Figure 2. Effect of inhibitors on cell viability. Lane 1, Control; lane 2 , cells treated with diallyl trisulfide (DATS; $100 \mu \mathrm{M}$ ); lane 3, cells treated with DATS $(100 \mu \mathrm{M})$ after being treated with SB203580 $(10 \mu \mathrm{M})$ for $30 \mathrm{~min}$; lane 4, cells treated with SB203580 $(10 \mu \mathrm{M})$; lane 5 , cells treated with DATS $(100 \mu \mathrm{M})$ after being treated with Z-LETD-FMK $(10 \mu \mathrm{M})$ for $30 \mathrm{~min}$; lane 6 , cells treated with ZLETD-FMK $(10 \mu \mathrm{M})$. Data are reported as means \pm SD of three independent experiments. ${ }^{*} \mathrm{P}<0.05$ compared to control (oneway ANOVA).

Figure 3. Apoptosis of CNE2 cells treated with diallyl trisulfide (DATS). CNE2 cells were treated with $0,50,100,150 \mu \mathrm{M}$ DATS for $24 \mathrm{~h}$. Apoptosis was determined by flow cytometry. Data are reported as means $\pm S D$ of three independent experiments. ${ }^{*} P<$ 0.05 compared to control (one-way ANOVA).
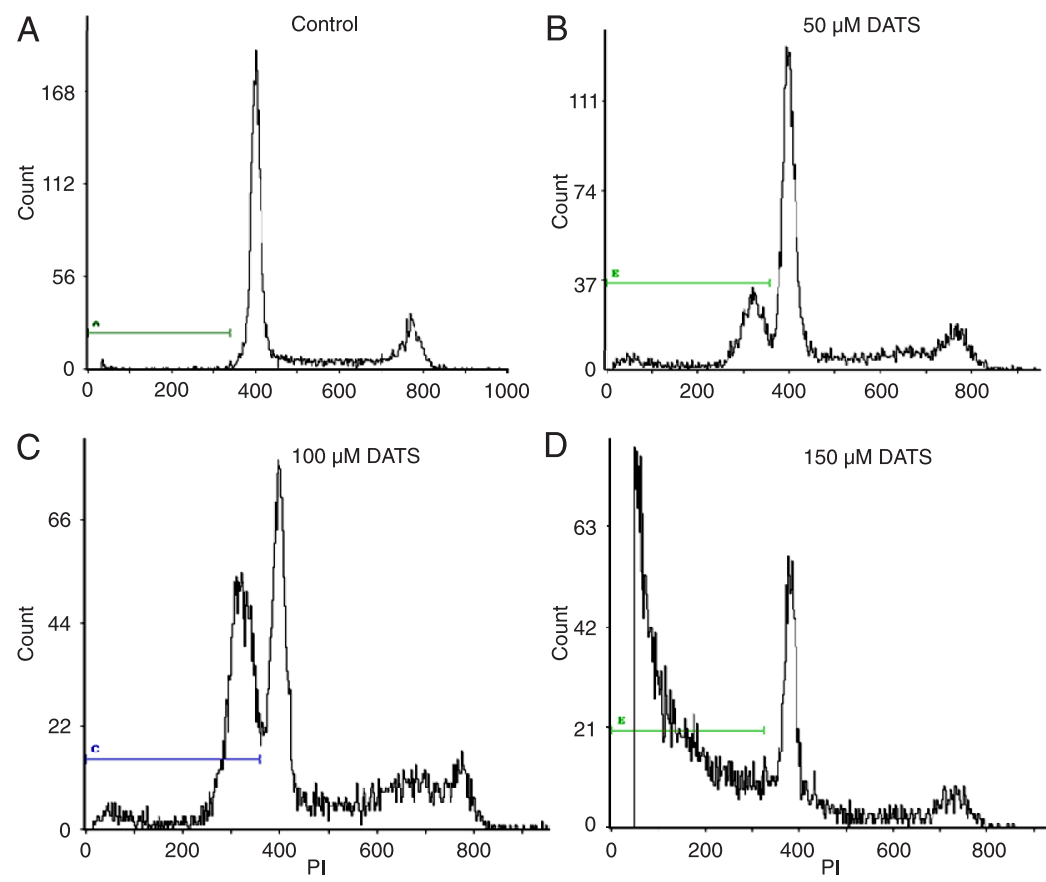

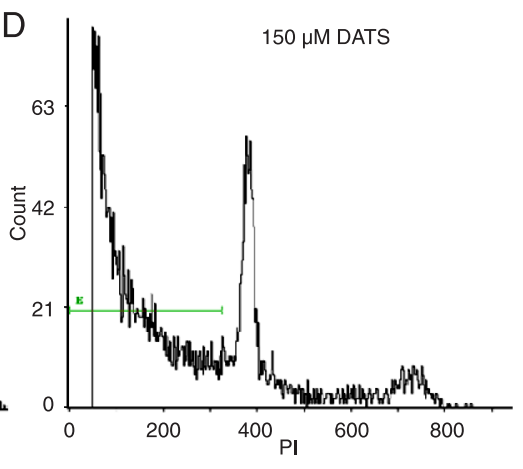

Figure 4. Effect of diallyl trisulfide (DATS) on apoptosis of CNE2 cells. $A$, Control; $B, C$, and $D$, CNE2 cells were treated with 50,100 , and $150 \mu \mathrm{M}$ DATS, respectively. The results are representative of three independent experiments. $\mathrm{PI}=$ propidium iodide. 
dependent manner.

We also determined the effects of both inhibitors on apoptosis by flow cytometry. Combined treatment with SB203580 plus DATS $(100 \mu \mathrm{M})$ increased the proportion of apoptotic CNE2 cells by an absolute value of $9.1 \%$ when compared with inhibitor treatment alone. CNE2 cell apoptosis was increased by $10 \%$ with Z-LETD-FMK plus DATS $(100 \mu \mathrm{M})$ compared with inhibitor treatment alone (Figures 5 and 6).

\section{Protein expression}

We tested the effects of DATS on p-p38 and caspase-8 activity as a function of dose by Western blotting. As shown in Figure 7, p-p38 and caspase-8 were markedly activated in a dose-dependent manner, with an accumulation of both after $24 \mathrm{~h}$ of DATS treatment. These data show that p-p38 and caspase-8 may play important roles in DATS-induced CNE2 cell apoptosis.

To test whether inhibitors block DATS-induced activation of p38 and caspase-8 in CNE2 cells, we also examined pro-

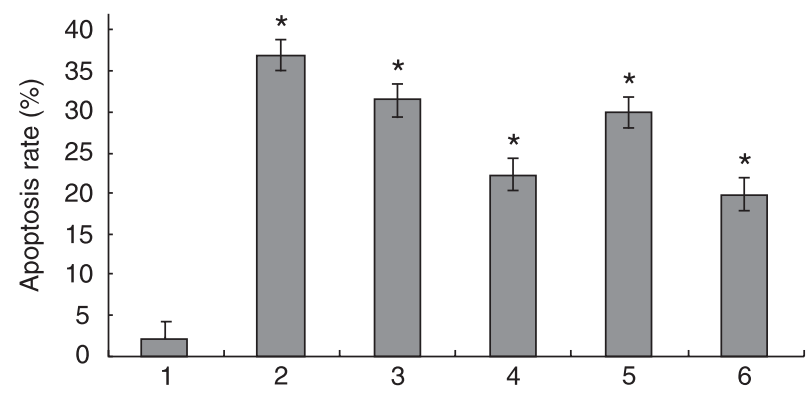

tein expression by Western blot analysis. When SB203580 or Z-LETD-FMK was added to CNE2 cells 30 min prior to DATS treatment, the activation of p-p38 and caspase-8 was markedly decreased. Similar results were observed with inhibitor treatment alone (Figure 8).

\section{Discussion}

Apoptosis is a type of physiological cell death that maintains body stability. The apoptosis process is strictly controlled by multiple genes, and malignant cell transformation is due, to a large extent, to the dysfunction of cell proliferation and death (23). The MAPK signal transduction pathway is an important signal transduction system for mediating extracellular stimulation of an intracellular response. A variety of extracellular stimuli can cause the phosphorylation chain reaction of the MAPK system, and this reaction can regulate cell proliferation, differentiation, apoptosis, and interactions $(24,25)$. In recent years, stud-

Figure 5. Apoptosis of CNE2 cells according to each treatment. Lane 1, Control; lane 2, cells treated with diallyl trisulfide (DATS) $(100 \mu \mathrm{M})$; lane 3 , cells treated with DATS $(100 \mu \mathrm{M})$ after being treated with SB203580 $(10 \mu \mathrm{M})$ for $30 \mathrm{~min}$; lane 4, cells treated with SB203580 $(10 \mu \mathrm{M})$; lane 5 , cells treated with DATS $(100 \mu \mathrm{M})$ after being treated with Z-LETD-FMK $(10 \mu \mathrm{M})$ for $30 \mathrm{~min}$; lane 6 , cells treated with Z-LETD-FMK $(10 \mu \mathrm{M})$. Data are reported as means $\pm S D$ of three independent experiments. ${ }^{*} P<0.05$ compared to control (one-way ANOVA).
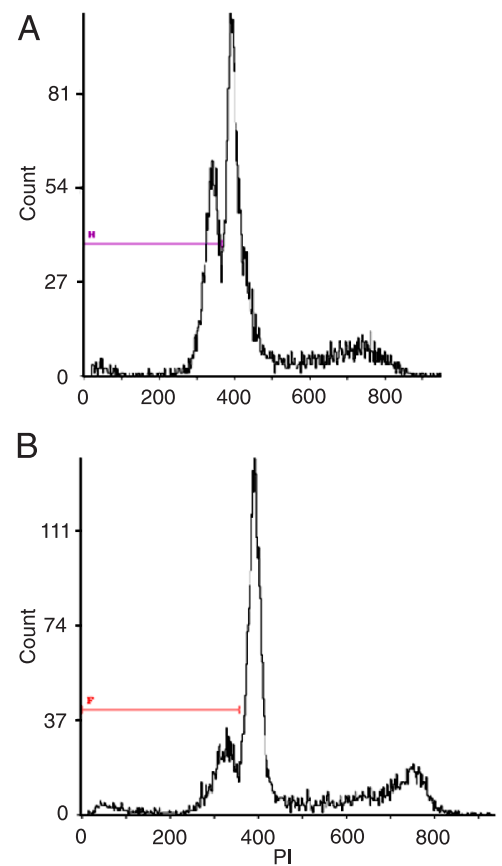

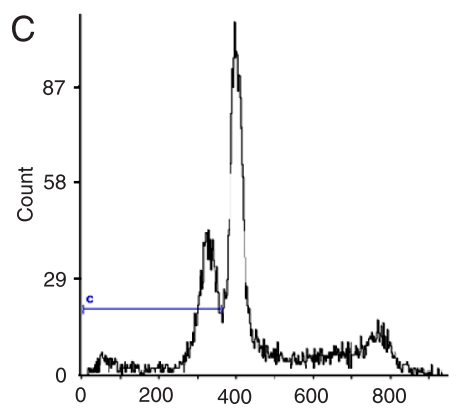

$\mathrm{D}$

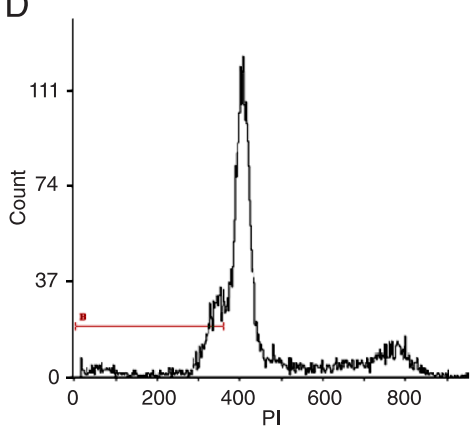

Figure 6. Effect of inhibitors on diallyl trisulfide (DATS)-induced apoptosis of CNE2 cells. $A$, Cells treated with DATS $(100 \mu \mathrm{M})$ after being treated with SB203580 $(10 \mu \mathrm{M})$ for 30 min; $B$, cells treated with SB203580 $(10 \mu \mathrm{M})$; $C$, cells treated with DATS $(100 \mu \mathrm{M})$ after being treated with Z-LETD-FMK $(10 \mu \mathrm{M})$ for 30 $\min ; D$, cells treated with Z-LETD-FMK (10 $\mu \mathrm{M})$. The results are representative of three independent experiments. $\mathrm{PI}=$ propidium iodide. 
A

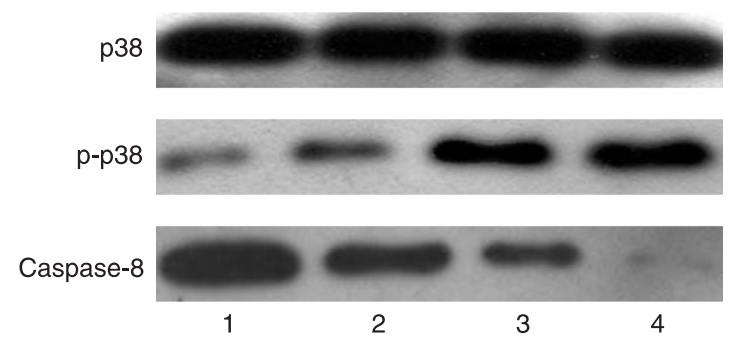

B

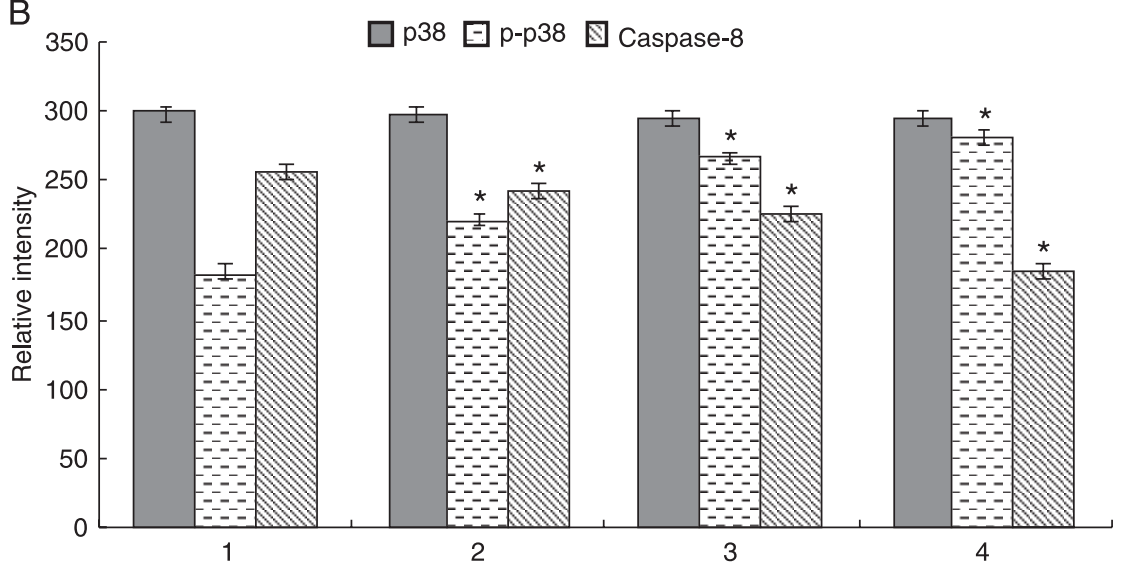

p38

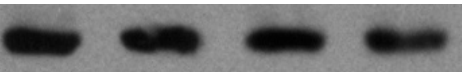

p-p38

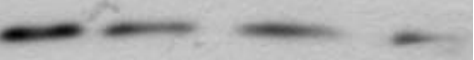

Caspase-8

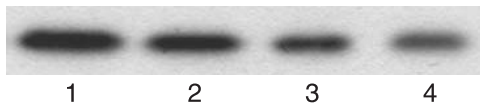

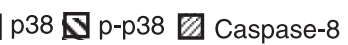

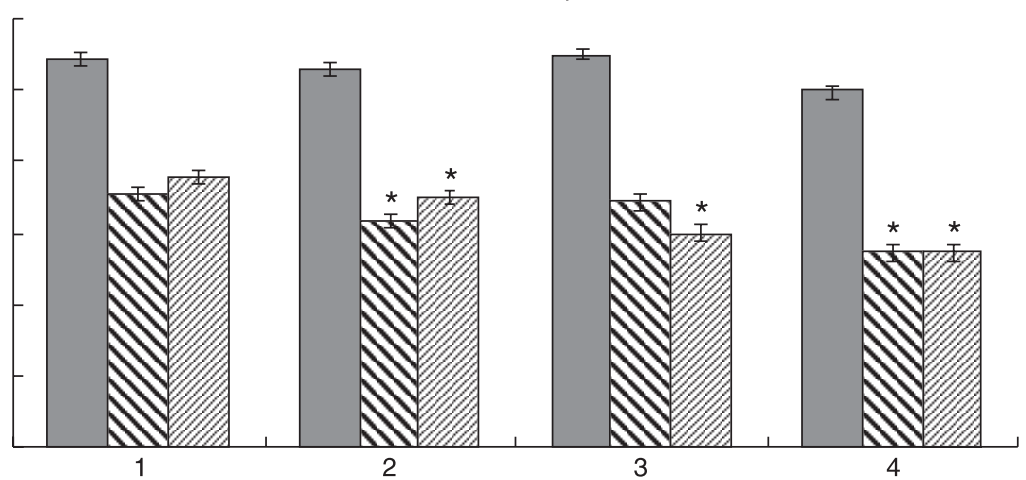

1

Figure 8. Effect of inhibition on protein expression determined by Western blotting. A, Lane 1, cells treated with diallyl trisulfide (DATS) $(100 \mu \mathrm{M})$ after being treated with SB203580 (10 $\mu \mathrm{M})$ for $30 \mathrm{~min}$; lane 2, cells treated with SB203580 (10 $\mu \mathrm{M})$; lane 3, cells treated with DATS $(100 \mu \mathrm{M})$ after being treated with Z-LETD-FMK $(10 \mu \mathrm{M})$ for $30 \mathrm{~min}$; lane 4, cells treated with ZLETD-FMK $(10 \mu \mathrm{M})$. B, Representative graphs of Western blot densities. Data are reported as means $\pm S D$ of three independent experiments. ${ }^{*} P<0.05$ compared to treatment with DATS + SB203580 (one-way ANOVA). 
ies have shown that the apoptosis signal transduction is closely related to the activation of caspase, whose family exist in mammalian cells, with 16 members of the family having been identified thus far. The caspase enzyme family is a central effector of apoptosis. The undynamic caspase will trigger apoptosis when it is activated, and play a very important role as the central effector of apoptosis when the cells start the apoptotic process (26-30).

To probe the relationship between p38MAPK and caspase-8 in the apoptosis process of human CNE2 cells induced by DATS, we pretreated CNE2 cells with SB203580 and Z-LETD-FMK, phosphospecific inhibitors of p38 and caspase-8, and then added DATS. The results presented in the present study established a potential role for inhibitors of p38MAPK and caspase-8 in DATS-induced apoptosis. First, the inhibitors (SB203580 or Z-LETD-FMK) showed inhibitory activity on p38MAPK and caspase-8. Second, a combined treatment with DATS and inhibitors (SB203580 or Z-LETD-FMK) reduced the inhibition and the apoptotic activity of CNE2 cells increased compared to cells treated with DATS alone (Figures 1, 2, 3, 5, 7, and 8). The

\section{References}

1. Donepudi M, MacSweeney A, Briand C, Grutter MG. Insights into the regulatory mechanism for caspase-8 activation. $\mathrm{Mol}$ Cell 2003; 11: 543-549.

2. Choi BM, Yoo KH, Bae IS, Oh MH, Hong YS, Lee JW, et al. Angiotensin-converting enzyme inhibition modulates mitogen-activated protein kinase family expressions in the neonatal rat kidney. Pediatr Res 2005; 57: 115-123.

3. Tian W, Zhang Z, Cohen DM. MAPK signaling and the kidney. Am J Physiol Renal Physiol 2000; 279: F593-F604.

4. Davis RJ. Signal transduction by the JNK group of MAP kinases. Cell 2000; 103: 239-252.

5. Johnson GL, Lapadat R. Mitogen-activated protein kinase pathways mediated by ERK, JNK, and p38 protein kinases. Science 2002; 298: 1911-1912.

6. Li SY, Yu B, An P, Wei JC, Zuo FY, Cai HY. Influence of FasL gene expression on hepatic metastasis of colorectal carcinoma. Hepatobiliary Pancreat Dis Int 2004; 3: 226-229.

7. Nagaraj NS, Anilakumar KR, Singh OV. Diallyl disulfide causes caspase-dependent apoptosis in human cancer cells through a Bax-triggered mitochondrial pathway. J Nutr Biochem 2010; 21: 405-412.

8. Qin L, Zhang X, Zhang L, Feng Y, Weng GX, Li MZ, et al. Downregulation of BMl-1 enhances 5-fluorouracil-induced apoptosis in nasopharyngeal carcinoma cells. Biochem Biophys Res Commun 2008; 371: 531-535.

9. Xie SM, Fang WY, Liu Z, Wang SX, Li X, Liu TF, et al. Lentivirus-mediated RNAi silencing targeting $A B C C 2$ increasing the sensitivity of a human nasopharyngeal carcinoma cell line against cisplatin. J Trans/ Med 2008; 6: 55.

10. Zhang YW, Wen J, Xiao JB, Talbot SG, Li GC, Xu M. Induction of apoptosis and transient increase of phosphorylated MAPKs by diallyl disulfide treatment in human nasopharyngeal carcinoma CNE2 cells. Arch Pharm Res 2006; 29: combined effect suggests a co-chemocytotoxic activity against human NPC. In conclusion, our results show that p38MAPK and caspase- 8 are involved in the process of DATS-induced apoptosis in human CNE2 cells and interact with each other.

At present, some progress has been made regarding the effect of the MAPK signaling pathway on cellular apoptosis, but in-depth study is still needed to fully reveal its mechanisms of action $(31,32)$. Our results show that the apoptosis process is strictly controlled by multiple genes and that $\mathrm{p} 38 \mathrm{MAPK}$ and caspase- 8 are involved in the process of DATS-induced apoptosis in human CNE2 cells, enhance DATS-induced apoptosis and interact with each other, but the mechanism involved needs further investigation. Further studies on the relationship between the MAPK signal transduction pathway and caspase in the cellular apoptosis process will lead to better clarification of the mechanism of apoptosis and will have important significance for the investigation of the anti-tumor mechanisms of DATS and for the design of new drugs.
$1125-1131$.

11. Kern M, Pahlke G, Balavenkatraman KK, Bohmer FD, Marko $D$. Apple polyphenols affect protein kinase $C$ activity and the onset of apoptosis in human colon carcinoma cells. J Agric Food Chem 2007; 55: 4999-5006.

12. Yoon H, Liu RH. Effect of selected phytochemicals and apple extracts on NF-kappaB activation in human breast cancer MCF-7 cells. J Agric Food Chem 2007; 55: 3167-3173.

13. Gayathri R, Gunadharini DN, Arunkumar A, Senthilkumar K, Krishnamoorthy G, Banudevi S, et al. Effects of diallyl disulfide (DADS) on expression of apoptosis associated proteins in androgen independent human prostate cancer cells (PC-3). Mol Cell Biochem 2009; 320: 197-203.

14. Sundaram SG, Milner JA. Diallyl disulfide induces apoptosis of human colon tumor cells. Carcinogenesis 1996; 17: 669673.

15. Kwon KB, Yoo SJ, Ryu DG, Yang JY, Rho HW, Kim JS, et al. Induction of apoptosis by diallyl disulfide through activation of caspase- 3 in human leukemia HL-60 cells. Biochem Pharmacol 2002; 63: 41-47.

16. Druesne-Pecollo N, Pagniez A, Thomas M, Cherbuy C, Duee PH, Martel P, et al. Diallyl disulfide increases CDKN1A promoter-associated histone acetylation in human colon tumor cell lines. J Agric Food Chem 2006; 54: 7503-7507.

17. Bottone FG Jr, Baek SJ, Nixon JB, Eling TE. Diallyl disulfide (DADS) induces the antitumorigenic NSAID-activated gene (NAG-1) by a p53-dependent mechanism in human colorectal HCT 116 cells. J Nutr 2002; 132: 773-778.

18. Wen J, Zhang Y, Chen X, Shen L, Li GC, Xu M. Enhancement of diallyl disulfide-induced apoptosis by inhibitors of MAPKs in human HepG2 hepatoma cells. Biochem Pharmacol 2004; 68: 323-331.

19. Park EK, Kwon KB, Park KI, Park BH, Jhee EC. Role of 
$\mathrm{Ca}(2+)$ in diallyl disulfide-induced apoptotic cell death of HCT-15 cells. Exp Mol Med 2002; 34: 250-257.

20. Hong YS, Ham YA, Choi JH, Kim J. Effects of allyl sulfur compounds and garlic extract on the expression of Bcl-2, Bax, and p53 in non small cell lung cancer cell lines. Exp Mol Med 2000; 32: 127-134.

21. Nakagawa H, Tsuta K, Kiuchi K, Senzaki H, Tanaka K, Hioki K, et al. Growth inhibitory effects of diallyl disulfide on human breast cancer cell lines. Carcinogenesis 2001; 22: 891-897.

22. Lu HF, Sue CC, Yu CS, Chen SC, Chen GW, Chung JG. Diallyl disulfide (DADS) induced apoptosis undergo caspase-3 activity in human bladder cancer T24 cells. Food Chem Toxicol 2004; 42: 1543-1552.

23. Widmann C, Gibson S, Jarpe MB, Johnson GL. Mitogenactivated protein kinase: conservation of a three-kinase module from yeast to human. Physiol Rev 1999; 79: 143180.

24. Tortora G, Bianco R, Daniele G, Ciardiello F, McCubrey JA, Ricciardi MR, et al. Overcoming resistance to molecularly targeted anticancer therapies: Rational drug combinations based on EGFR and MAPK inhibition for solid tumours and haematologic malignancies. Drug Resist Updat 2007; 10: 81-100.

25. Marks N, Berg MJ. Recent advances on neuronal caspases in development and neurodegeneration. Neurochem Int 1999; 35: 195-220.

26. Henkels KM, Turchi JJ. Cisplatin-induced apoptosis pro- ceeds by caspase-3-dependent and -independent pathways in cisplatin-resistant and -sensitive human ovarian cancer cell lines. Cancer Res 1999; 59: 3077-3083.

27. Chen YC, Shen SC, Lee WR, Hsu FL, Lin HY, Ko CH, et al. Emodin induces apoptosis in human promyeloleukemic $\mathrm{HL}$ 60 cells accompanied by activation of caspase 3 cascade but independent of reactive oxygen species production. Biochem Pharmacol 2002; 64: 1713-1724.

28. Hofmanova J, Vaculova A, Kozubik A. Polyunsaturated fatty acids sensitize human colon adenocarcinoma HT-29 cells to death receptor-mediated apoptosis. Cancer Lett 2005; 218: 33-41.

29. Wen J, Wang XC, Zhang YW, Nie YL, Talbot SG, Li GC, et al. Mitogen-activated protein kinase inhibitors induce apoptosis and enhance the diallyl disulfide-induced apoptotic effect in human CNE2 cells. J Health Sci 2008; 54: 129-136.

30. Xiao D, Choi S, Johnson DE, Vogel VG, Johnson CS, Trump $\mathrm{DL}$, et al. Diallyl trisulfide-induced apoptosis in human prostate cancer cells involves c-Jun N-terminal kinase and extracellular-signal regulated kinase-mediated phosphorylation of Bcl-2. Oncogene 2004; 23: 5594-5606.

31. Fan Y, Chen H, Qiao B, Luo L, Ma H, Li H, et al. Opposing effects of ERK and p38 MAP kinases on HeLa cell apoptosis induced by dipyrithione. Mol Cells 2007; 23: 30-38.

32. Wu JH, Hong LC, Tsai YY, Chen HW, Chen WX, Wu TS. Mitogen-activated protein kinase (MAPK) signalling pathways in HepG2 cells infected with a virulent strain of Klebsiella pneumoniae. Cell Microbiol 2006; 8: 1467-1474. 